\title{
Impact and Correlation of Air Quality and Climate Variables with COVID-19 Morbidity and Mortality in Dhaka, Bangladesh
}

\section{Md Riad Sarkar Pavel', Abdus Salam ${ }^{1 *}$ Mahbuba Yesmin², Nazmul Ahsan², Shahid Uz Zaman ${ }^{1}$ and Farah Jeba'}

\footnotetext{
${ }^{1}$ Department of Chemistry, Faculty of Science, University of Dhaka, Dhaka-1000, Bangladesh.

${ }^{2}$ Enam Medical College and Hospital, Department of Medicine, Savar, Dhaka Bangladesh

${ }^{3}$ Department of Genetic Engineering and Biotechnology, Faculty of Biological Sciences, University of Dhaka, Dhaka-1000, Bangladesh
}

*Corresponding author: +8801817061160; asalam@gmail.com; asalam@du.ac.bd

\section{medRxiv}

September 2020 


\begin{abstract}
The COVID-19 pandemic unexpectedly stopped the steady life and enhanced environmental quality. To apprehend the transmission of COVID-19 and the improvement of air quality, we have studied air quality indicators $\left(\mathrm{PM}_{2.5}, \mathrm{PM}_{10}, \mathrm{AQI}\right.$, and $\left.\mathrm{NO}_{2}\right), \mathrm{CO}_{2}$ emission, and climate variables (temperature, relative humidity, rainfall, and wind velocity) in the extremely polluted and densely populated Southeast Asian megacity Dhaka, Bangladesh from March to June 2020. The Kendall and Spearman correlations were chosen to test the connotation of air quality and climate variables with COVID-19 morbidity and mortality. The average concentrations of $\mathrm{PM}_{2.5}, \mathrm{PM}_{10}$, and $\mathrm{CO}_{2}$ were 65.0 \pm 37.9 and $87.1 \pm 52.8 \mu \mathrm{m} \mathrm{m}^{-3}$, and $427 \pm 11.8 \mathrm{ppm}$, respectively. The average $\mathrm{PM}_{2.5}$ and $\mathrm{PM}_{10}$ drastically reduced up to 62\% during COVID-19 lockdown in Dhaka comparing with March 2020 (before lockdown). Comparing with the same period in 2019, $\mathrm{PM}_{2.5}$ reduced up to $33.5 \%$. The average $\mathrm{NO}_{2}$ concentration was $35.0 \mu \mathrm{mol} \mathrm{m}{ }^{-2}$ during the lockdown period in April, whereas 175.0 $\mu \mathrm{mol} \mathrm{m} \mathrm{m}^{-2}$ during March (before lockdown). A significant correlation was observed between COVID-19 cases and air quality indicators. A strong correlation was obtained between climate variables and the total number of COVID-19 morbidity and mortality representing a favorable condition for spreading the virus. Our study will be very expedient for policymakers to establish a mechanism for air pollution mitigation based on scientific substantiation, and also will be an essential reference for the advance research to improve urban air quality and the transmission of the SARS-CoV-2 virus in the tropical nations.
\end{abstract}

Keywords: COVID-19; air quality indicators; $\mathrm{PM}_{2.5}$ and $\mathrm{PM}_{10}$; climate variables; Kendall and Spearman correlation. 
medRxiv preprint doi: https://doi.org/10.1101/2020.09.12.20193086; this version posted September 13, 2020. The copyright holder for this preprint (which was not certified by peer review) is the author/funder, who has granted medRxiv a license to display the preprint in perpetuity.

It is made available under a CC-BY 4.0 International license .

\section{Highlights:}

- COVID-19 lockdown drastically reduced $\mathrm{PM}_{2.5}$ and $\mathrm{PM}_{10}$ concentrations up to $62 \%$.

- During lockdown, $\mathrm{NO}_{2}$ emission abridged up to $80 \%, \mathrm{CO}_{2}$ emission dropped by $2-4 \%$.

- Climate variables revealed strong correlation with COVID-19 morbidity and mortality.

- COVID-19 cases and mortality had significant correlation with air quality indicators.

- Knowledge from enormous improved air quality will be transmitted to the policy execution.

\section{Graphical Abstract:}

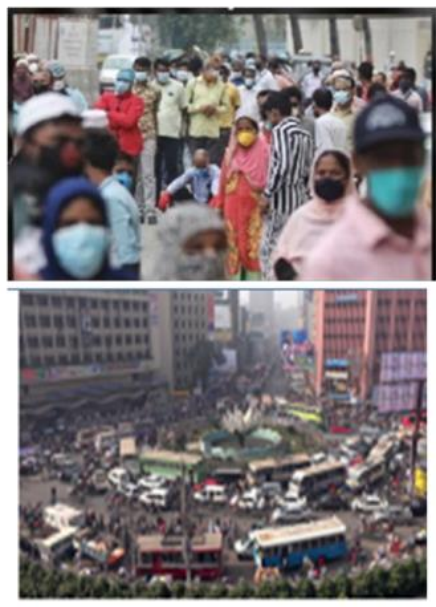

Before lockdown
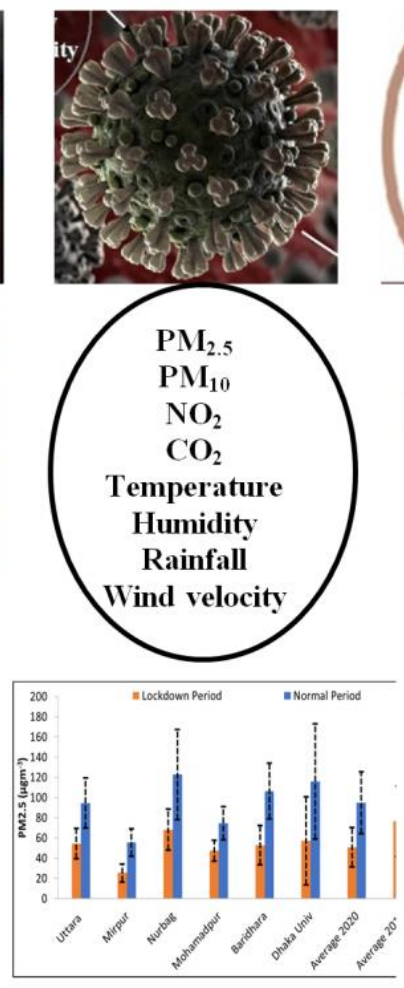
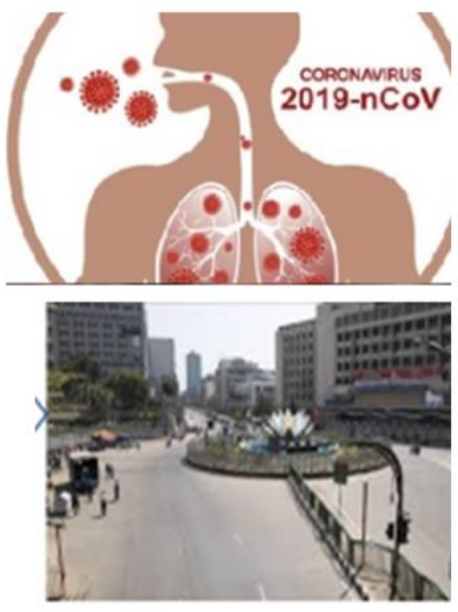

During lockdown
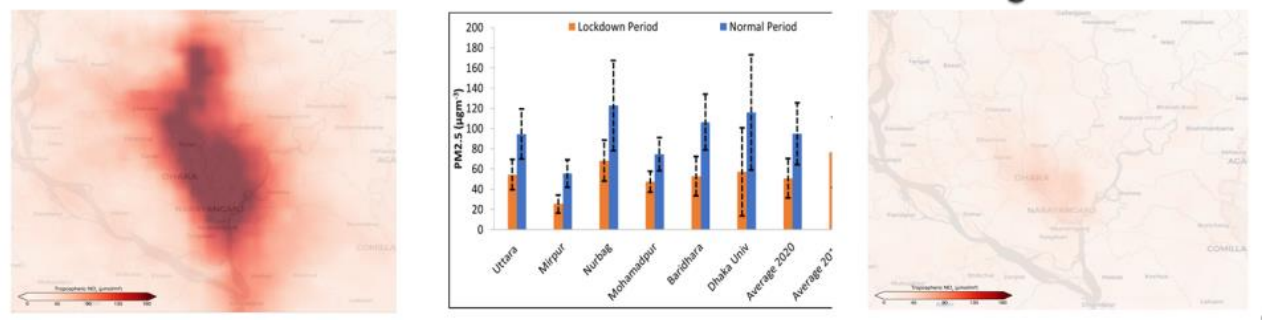


\section{Introduction}

The COVID-19 pandemic has been progressing in 213 countries and territories all over the world (Hopkins, 2020). It has been a devastating attack in China, Italy, France, Spain, United States, Brazil, and many other countries (Hopkins, 2020; WHO, 2020b). In December 2019, COVID-19 started as an epidemic event in Wuhan, China having 11 million inhabitants in the central Hubei Province. People were suffering from pneumonia as the result of infection of this novel coronavirus (Li et al., 2020, Wu et al., 2020a). This virus was termed as SARS-CoV-2 on January 7, 2020, for its similarity with global epidemic Severe Acute Respiratory Syndrome (SARS) that occurred between 2002 and 2003. The severe respiratory complications are causing caused the epidemic and officially termed as COVID-19 on February 11, 2020 (Xu et al., 2020, WHO, 2020a). SARS-CoV2 contains a positive-sense, single-stranded RNA and which has a size of approximately $120 \mathrm{~nm}$ in diameter spreading through droplets transmission (Shereen et al., 2020). The most severe symptoms were generally observed in older individuals having previous comorbidities, such as cardiovascular, endocrine, digestive, and respiratory diseases (Sohrabi et al., 2020, Wang et al., 2020a). Up to June 16, 2020, over 443,281 have lost their lives due to COVID-19 infection in the entire world out of $8,196,036$ infections on average of $5.41 \%$ mortality rate (https://www.worldometers.info). The virus has transmitted worldwide but, nowadays, some countries are recovering from the new transmission. However, in some regions of the world, particularly Southeast Asian countries (e.g., Bangladesh, India), the COVID-19 infection scenario is worsening day by day. Poor standard of living, limited health care facilities, high population density, worst air quality, and climatevulnerable situation make the people of this region more endangered towards infection. 
medRxiv preprint doi: https://doi.org/10.1101/2020.09.12.20193086; this version posted September 13, 2020. The copyright holder for this preprint (which was not certified by peer review) is the author/funder, who has granted medRxiv a license to display the preprint in perpetuity.

It is made available under a CC-BY 4.0 International license.

In Bangladesh, the first cases of COVID-19 were reported on March 8, 2020, and the first death of COVID-19 patient on March 18, 2020, by the Institute of Epidemiology, Disease Control and Research (IEDCR) (https://iedcr.gov.bd/). As of June 16, 2020, Bangladesh has seen a total COVID-19 infection of 94,481; total recovered of 36,262 and total death of 1,262 (mortality rate was $1.3 \%$ based on confirmed cases). The greater Dhaka region has become the epicenter of COVID-19 new cases and deaths in Bangladesh (https://iedcr.gov.bd/). The lockdown was enforced on 26th March 2020, which ended on 30th May 2020. This long-term lockdown affected industrial production, educational institutes, construction activities, small and large scale businesses. It created a huge negative impact on the economy and a large group of people is facing a crisis for their daily livings. Due to the uncontrolled situation of COVID-19, the Government of Bangladesh again instigated regional lockdown depending on the number of infected people on June 16, 2020, marked as a red, yellow, and green zone. During the lockdown, nature has got an opportunity for healing as dwellers are maintaining social distancing, quarantine at home, minimum outside activities. Therefore, we saw the blue sky in Dhaka city during the lockdown period (more than 100 days). Air quality has also substantially improved compared to the previous years in Dhaka like other cities in the World, e.g., Delhi, (-60\%), Seoul (-54\%), Wuhan (-44\%), and Los Angeles (-31\%) (IQAir, 2020).

However, air quality was not improved significantly in the entire world. It has improved a lot in some cities but other cities it did not change at all, and the cause was not the COVID-19 lockdown only (Schiermeier, 2020). For example, a significant reduction in Los Angles, USA was not clear, either for COVID-19 precautions or falling rain during this period (Schiermeier, 2020). In the absence of traffic vehicles and control industrial activities, several air pollutants in China declined 
up to $90 \%$ during COVID-19 pandemic (Le et al., 2020) (a reduction of $22.8 \mu \mathrm{g} \mathrm{m}^{-3} \mathrm{NO}_{2}$ and 18.9

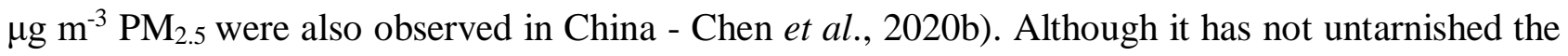
role of aerosol particles in the transmission of the SAR-CoV-2 virus, long-term high-level exposure to air pollutants may have protracted vulnerability and mortality rates of COVID-19, (Liu et al., 2020).

Some studies reported the relationship between the number of confirmed COVID-19 positive cases and climate variables, e.g., temperatures, humidity (Bukhari and Jameel, 2020; Ma et al., 2020). Bukhari and cols, 2020 reported that the low number of positive COVID-19 confirmed cases observed in tropical countries might be explained due to their usual warm and humid environmental conditions. The regions with high relative humidity above $10 \mathrm{~g} \mathrm{~m}^{-3}$ could see a slowdown of COVID-19 transmissions in a short time (Bukhari and Jameel, 2020). Ma and cols, 2020 also revealed that the temperature and humidity were affecting factors related to the number of COVID19 mortality in Wuhan, China (Ma et al., 2020).

Therefore, we would like to quantify the effect of lockdown on air quality parameters $\left(\mathrm{PM}_{10}, \mathrm{PM}_{2.5}\right.$, $\mathrm{NO}_{2}$, and $\mathrm{CO}_{2}$ ) and also would like to elucidate the correlation between climate variables (temperature, relative humidity, rainfall, and wind velocity) and air quality indicators with COVID19 morbidity and mortality in Dhaka, Bangladesh.

\section{Research Methodology}

Dhaka is the capital city of Bangladesh and the center of the Government, trade, and culture of the country. Geographically, Dhaka is located in the center of Bangladesh between $23^{\circ} 22^{\prime} 30^{\prime \prime} \mathrm{N}$ to $24^{\circ} 22^{\prime} 20^{\prime \prime} \mathrm{N}$ and $89^{\circ} 41^{\prime} 6^{\prime \prime}$ E to $90^{\circ} 59^{\prime} 23^{\prime \prime} \mathrm{E}$, on the eastern banks of the Buriganga River (Fig. 1). 


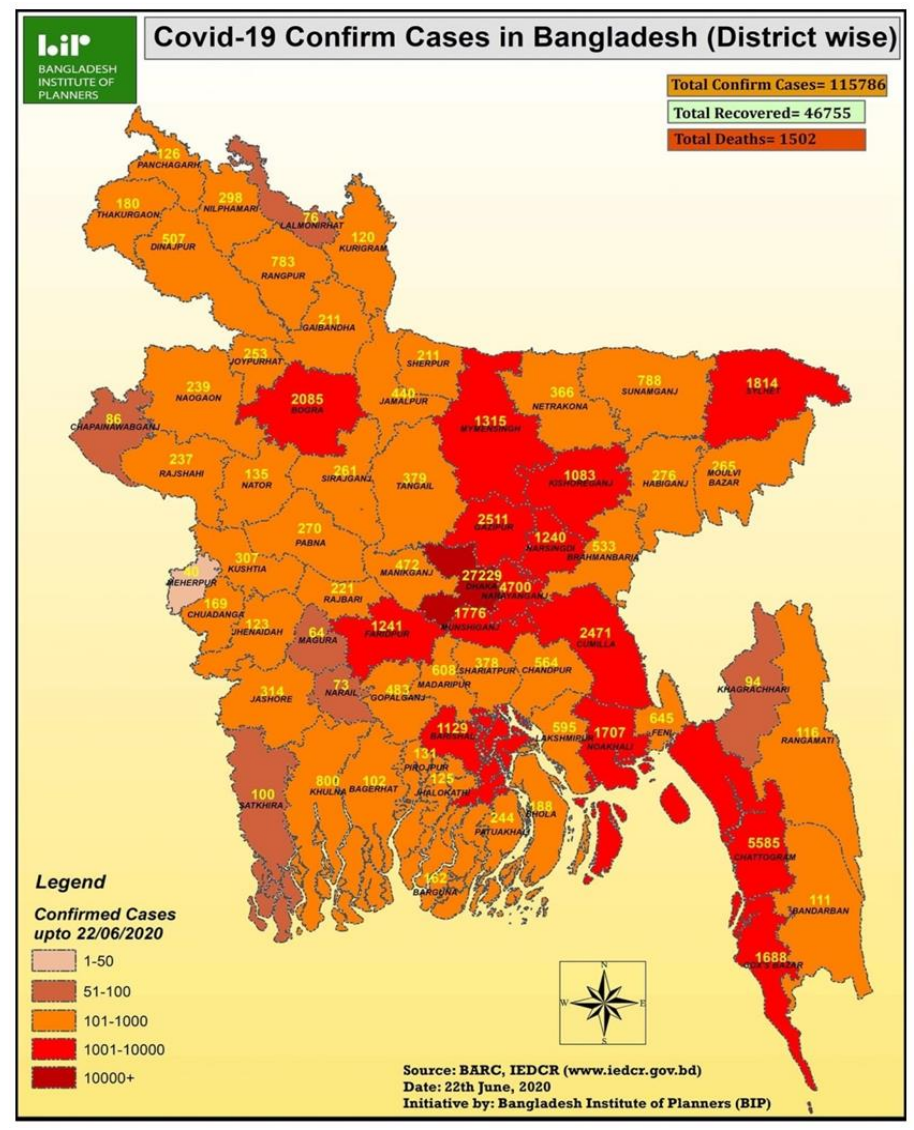

Fig. 1. Distribution of COVID-19 confirmed cases in 64 districts of Bangladesh until June 22, 2020 (Source: Bangladesh Institute of Planners).

The climate of Bangladesh is generally hot and humid. Meteorologically, Bangladesh can be subdivided into four seasons. Pre-monsoon (March-May), Monsoon (June-August), Post-monsoon (September-November), and winter (December- January) (Salam et al., 2012; Salam et al., 2003). The maximum summer temperature ranges from $30^{\circ} \mathrm{C}$ to $40^{\circ} \mathrm{C}$. April is the warmest month and, January is the coldest month in general. The temperature drops to $10^{\circ} \mathrm{C}$ on average across the country during winter. The effect of monsoon climate is heavy rainfall. The maximum precipitation is 103.6 inches, the minimum is 46.1 inches while the average is 63.4 inches. Dhaka is the most 
medRxiv preprint doi: https://doi.org/10.1101/2020.09.12.20193086; this version posted September 13, 2020. The copyright holder for this preprint (which was not certified by peer review) is the author/funder, who has granted medRxiv a license to display the preprint in perpetuity.

It is made available under a CC-BY 4.0 International license .

densely populated megacity in the World with 21 million people residing within 1462.6 square kilometers. The wind direction follows the general trend of south and south-west in the premonsoon and north and north-west in the winter (Salam et al., 2003).

This study includes two stages of analysis: 1) to assess the effect of lockdown on air quality indicators $\left(\mathrm{PM}_{2.5}\right.$ and $\left.\mathrm{PM}_{10}\right), \mathrm{CO}_{2}$ emission, and 2) to study the correlation of climate variables (average temperature, relative humidity, rainfall, and wind velocity) and air quality parameters with COVID-19 morbidity and mortality. The Kendall and Spearman rank correlation tests were utilized to examine the correlation between variables and air quality parameters. Air quality data of Dhaka was obtained from our measurements at the Mukarram Hussain Khundker Building, University of Dhaka. Data set for COVID-19 was taken from the COVID-19 archive from the Directorate General of Health Services (DGHS) (www.dghs.gov.bd). Data on climate variables (average, relative humidity, wind speed, and rainfall) was taken from weatherforyou.com and darksky.net.

\section{Results and Discussion}

\section{Overview of the Air Quality and Climate variables}

The summary of $\mathrm{PM}_{2.5}, \mathrm{PM}_{10}, \mathrm{CO}_{2}$, temperature, relative humidity, wind velocity, and rainfall between March 8 (1st day of confirmed COVID-9 cases in Bangladesh) and June 16, 2020, in Dhaka megacity has been given in Table 1 . The total average $\mathrm{PM}_{2.5}$ and $\mathrm{PM}_{10}$ were $65.0 \pm 37.9$ and $87.1 \pm 52.8 \mu \mathrm{g} \mathrm{m}^{-3}$, which were about 2.6 and 1.7 times higher than WHO guideline values for $24 \mathrm{~h}$ average, respectively. The average $\mathrm{PM}_{2.5}$ was $50.8 \pm 19.6 \mu \mathrm{g} \mathrm{m}^{-3}$ during the lockdown and $94.9 \pm$ $30.6 \mu \mathrm{g} \mathrm{m}^{-3}$ before lockdown in Dhaka megacity. The lowest average relative humidity was $39.1 \%$, the highest was $99.8 \%$, and the average rainfall was $0.23 \pm 0.31$ inch hour ${ }^{-1}$. The average $\mathrm{CO}_{2}$ 
medRxiv preprint doi: https://doi.org/10.1101/2020.09.12.20193086; this version posted September 13, 2020. The copyright holder for this preprint (which was not certified by peer review) is the author/funder, who has granted medRxiv a license to display the preprint in perpetuity.

It is made available under a CC-BY 4.0 International license .

emission was $427 \pm 11.8 \mathrm{ppm}$, which is slightly lower (456 $\pm 63.4 \mathrm{ppm}$ ) than the value in January 2020.

Table 1. Summary of statistical values of air quality and climate variables from March 8 to June 16, 2020 in Dhaka University Area, Dhaka, Bangladesh.

\begin{tabular}{|c|c|c|c|c|c|c|c|}
\hline & $\begin{array}{c}\mathbf{P M}_{2.5} \\
\left(\mu \mathrm{g} \mathrm{m}^{-3}\right)\end{array}$ & $\begin{array}{c}\text { PM }_{10} \\
\left(\mu \mathrm{g} \mathrm{m}^{-3}\right)\end{array}$ & $\begin{array}{c}\mathrm{CO}_{2} \\
(\mathrm{ppm})\end{array}$ & $\begin{array}{c}\text { Temp } \\
\left({ }^{\circ} \mathrm{C}\right)\end{array}$ & $\begin{array}{c}\text { Humidity } \\
(\%)\end{array}$ & $\begin{array}{c}\text { Rainfall } \\
\left(\text { inch hour }^{-1} \text { ) }\right.\end{array}$ & $\begin{array}{c}\text { Wind velocity } \\
\left(\mathbf{m ~ h}^{-1}\right)\end{array}$ \\
\hline Average & 65.0 & 87.1 & 427.5 & 29.3 & 73.8 & 0.23 & 6.5 \\
\hline Median & 57.8 & 76.8 & 425.1 & 29.4 & 76.0 & 0.08 & 6.0 \\
\hline S.D. & 37.9 & 52.8 & 11.8 & 2.1 & 12.9 & 0.31 & 3.1 \\
\hline $\operatorname{Max}$ & 207.4 & 272.6 & 465.8 & 33.6 & 99.8 & 1.59 & 18.3 \\
\hline Min & 17.3 & 19.7 & 408.3 & 23.9 & 39.1 & 0.00 & 2.0 \\
\hline
\end{tabular}

As control measures during COVID-19 pandemic, precautions, such as lockdown were enforced by restricting vehicle movements, closing government offices, schools, colleges, universities, shopping malls, and "stay in home order" on March 26, 2020, have been taken by the Government of Bangladesh. Due to the restrictions, the concentrations of $\mathrm{PM}_{2.5}$ and $\mathrm{PM}_{10}$ have reduced drastically up to $62 \%$ during April. The times series of daily average concentrations of $\mathrm{PM}_{2.5}, \mathrm{PM}_{10}$, and $\mathrm{CO}_{2}$ have given in Figs. 2(a), 2(b) and 2(c) mentioning the events, e.g., lockdown begins, Garments industry open, Eid festival, lockdown ends and offices, etc. The daily average global $\mathrm{CO}_{2}$ were also drastically reduced up to $17 \%$ with a maximum of $26 \%$ and a minimum of $4 \%$ in the early April compared to the previous year in 2019 due to the restricted activates during COVID-19 pandemic 
medRxiv preprint doi: https://doi.org/10.1101/2020.09.12.20193086; this version posted September 13, 2020. The copyright holder for this preprint (which was not certified by peer review) is the author/funder, who has granted medRxiv a license to display the preprint in perpetuity. It is made available under a CC-BY 4.0 International license .

(Le Quéré et al., 2020). In general, the values of the air quality parameters were getting lower with the progress of the lockdown (Fig. 2). When the lockdown was curbed on May 30, 2020, we can see, the concentrations of the air quality parameters were rising slowly in Dhaka.
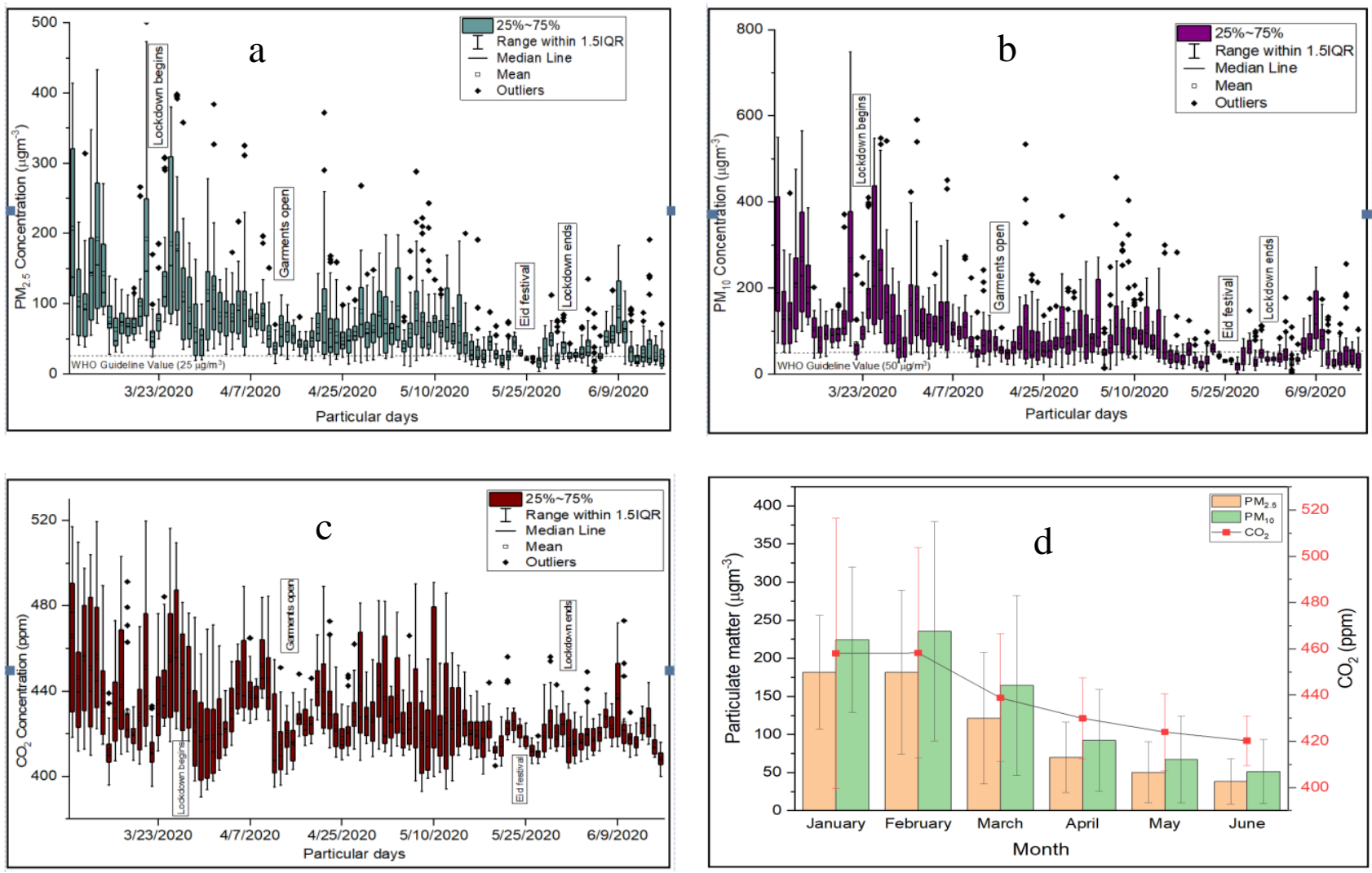

Fig. 2. $(\mathrm{a}, \mathrm{b}, \mathrm{c})$. The daily average concentrations of $\mathrm{PM}_{2.5}, \mathrm{PM}_{10}$, and $\mathrm{CO}_{2}$; and 2(d). Monthly average concentrations of $\mathrm{PM}_{2.5}, \mathrm{PM}_{10}$, and $\mathrm{CO}_{2}$ at Mukarram Hussain Khundker Building, University of Dhaka, Bangladesh.

The monthly average concentrations of $\mathrm{PM}_{10}, \mathrm{PM}_{2.5}$, and $\mathrm{CO}_{2}$ emission were getting lower from January through June 2020. January and February were almost similar but much higher than April, May, and June. The reduction was not only for COVID-19 precautions activities, but also rainfall 
medRxiv preprint doi: https://doi.org/10.1101/2020.09.12.20193086; this version posted September 13, 2020. The copyright holder for this preprint (which was not certified by peer review) is the author/funder, who has granted medRxiv a license to display the preprint in perpetuity.

It is made available under a CC-BY 4.0 International license .

from April to June (Fig. 2(d)), especially for $\mathrm{PM}_{2.5}, \mathrm{PM}_{10}$, and $\mathrm{CO}_{2}$ ), but $\mathrm{NO}_{2}$ reduction in April 2020 is only for traffic emission (Fig. 5). However, we have identified and quantified the contribution of reduction in air quality indicators due to COVID-19 lockdown by comparing it with the same period of the previous year 2019 (Fig. 3 and Fig. 4). As a case study, we have differentiated between "before lockdown" and "during lockdown" $\mathrm{PM}_{2.5}$ emission in Fig. 3.

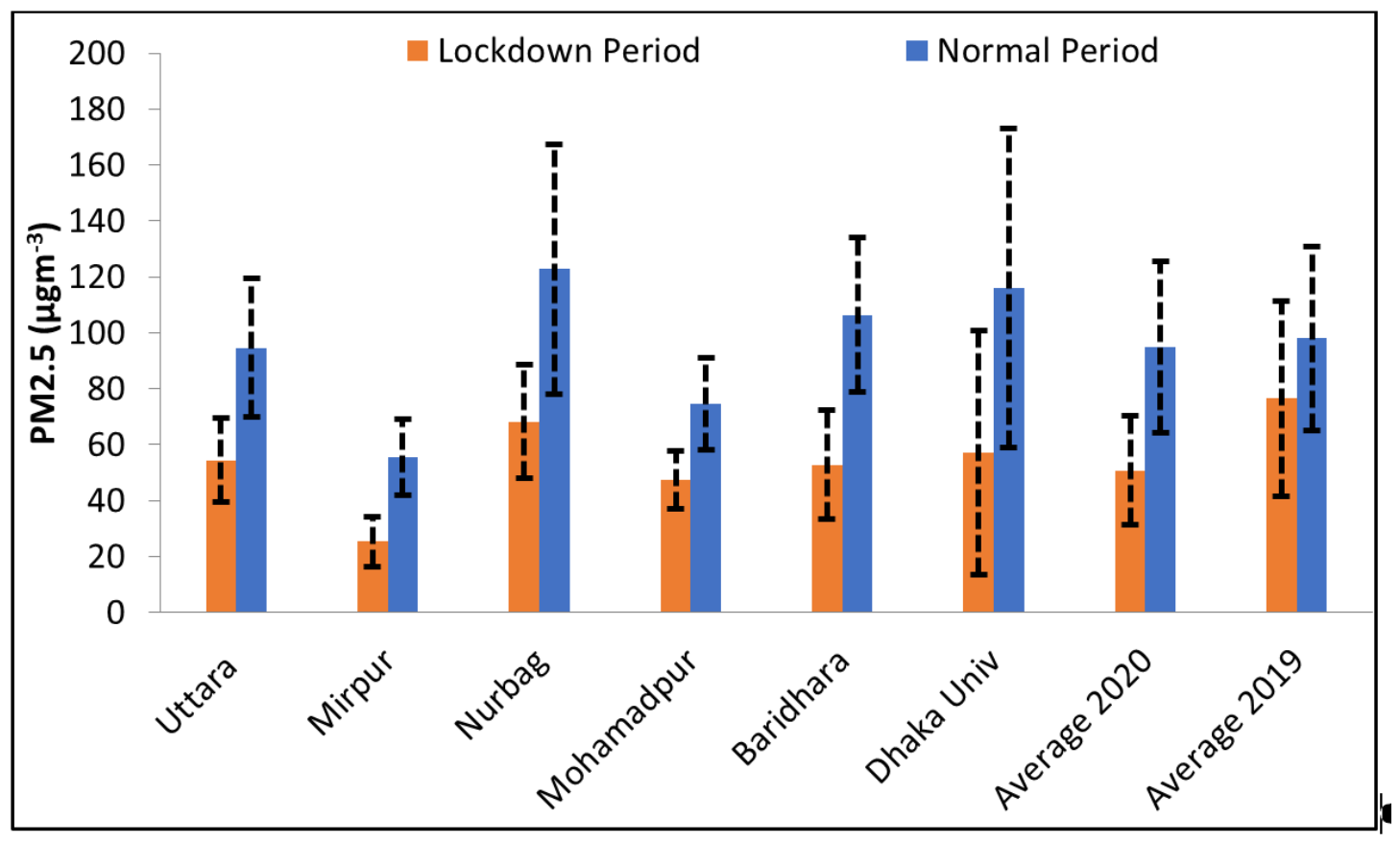

Fig. 3. $\mathrm{PM}_{2.5}$ concentrations between normal (March 16-27, 2020) and lockdown (March 28-May 30, 2020) periods at five different locations in Dhaka, Bangladesh. The average $\mathrm{PM}_{2.5}$ concentrations of the same time period in 2019 have also been given for comparison.

Several recent papers reported that a decline in $\mathrm{PM}_{2.5}$ is associated with lockdown and affected COVID-19 transmission (Chauhan and Singh, 2020; Sharma et al., 2020). The data of the $\mathrm{PM}_{2.5}$ concentrations were analyzed at five different locations in Dhaka city before lockdown (March 16- 
medRxiv preprint doi: https://doi.org/10.1101/2020.09.12.20193086; this version posted September 13, 2020. The copyright holder for this preprint (which was not certified by peer review) is the author/funder, who has granted medRxiv a license to display the preprint in perpetuity.

It is made available under a CC-BY 4.0 International license .

27, 2020) and after lockdown (March 28-May 30, 2020) to see the variations in Dhaka city, and also made a comparison with the same period in 2019 (Fig. 3). The average $\mathrm{PM}_{2.5}$ decline during the lockdown period was $42.3 \%$ in Uttara, $31.6 \%$ in Mirpur, $57.4 \%$ at Nurbag, Kamrangirchar, $28.8 \%$ in Mohammadpur, 56.5\% in Baridhara, 62\% in Dhaka University area (Fig. 3). The overall average $\mathrm{PM}_{2.5}$ decreased by about $46.6 \%$ during the lockdown period. The average $\mathrm{PM}_{2.5}$ value during the lockdown period in 2020 also decreased by $33.5 \%$ compared to the last year (2019), but regular period values of $\mathrm{PM}_{2.5}$ were almost similar between 2020 and 2019 (Fig. 3).

The satellite images of $\mathrm{NO}_{2}$ distribution over the Dhaka city have been given in Fig. 4 at different periods before and during the lockdown, and also during limited scale lockdown in 2020; and also, for a similar period in 2019. It has clearly shown the significant reduction of $\mathrm{NO}_{2}$ concentration during the lockdown period in April 2020 (about $35 \mu \mathrm{mol} \mathrm{m}$ ), whereas it was about $170 \mu \mathrm{mol} \mathrm{m} \mathrm{m}^{-2}$ before lockdown over Dhaka.

The comparison between April 13-27 in 2020 and April 15-29 in 2019 was also indicating a very drastic reduction of $\mathrm{NO}_{2}$ concentration over Dhaka. During April 2020, the vehicles were very limited in the street of Dhaka due to the complete shutdown of offices, schools, colleges, universities, constructions, industries, and also "stay in-home" order. These are the major causes of the drastic reduction of $\mathrm{NO}_{2}$ over Dhaka city because the foremost source of $\mathrm{NO}_{2}$ emissions is from traffic vehicles. The $\mathrm{NO}_{2}$ reduction was $40 \%$ (on average) in many cities of China, $20-38 \%$ in Western Europe and the USA during COVID-19 lockdown compared to the same period in 2019 (Bauwens et al., 2020). 
medRxiv preprint doi: https://doi.org/10.1101/2020.09.12.20193086; this version posted September 13, 2020. The copyright holder for this preprint (which was not certified by peer review) is the author/funder, who has granted medRxiv a license to display the preprint in perpetuity.

It is made available under a CC-BY 4.0 International license .

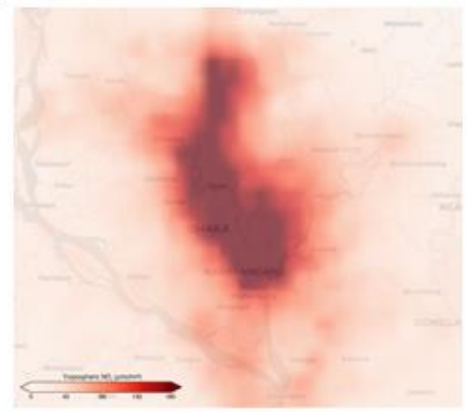

February 24-March 9, 2020

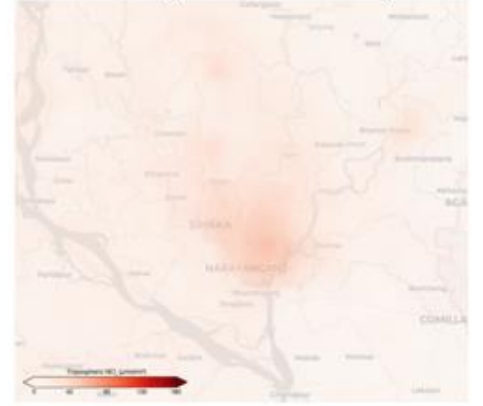

April 6-20, 2020

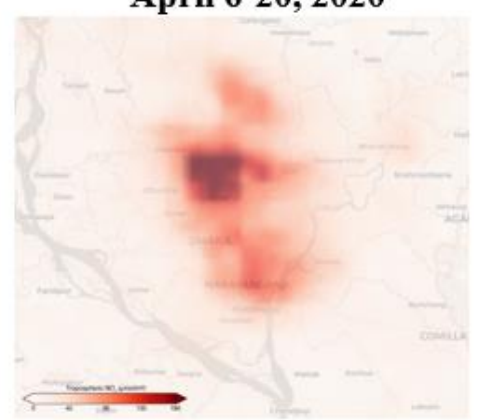

May 4-18, 2020

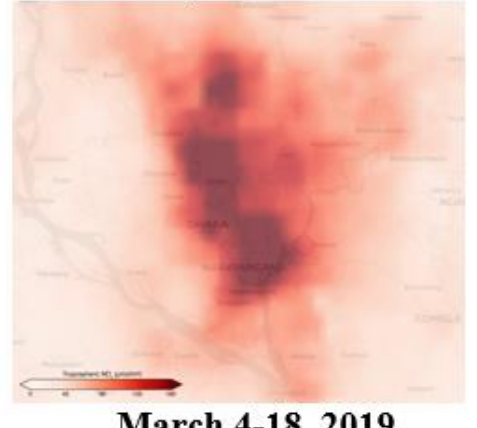

March 4-18, 2019

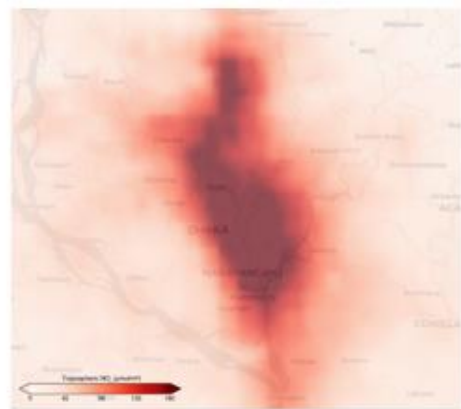

March 2-16, 2020



April 13-27, 2020

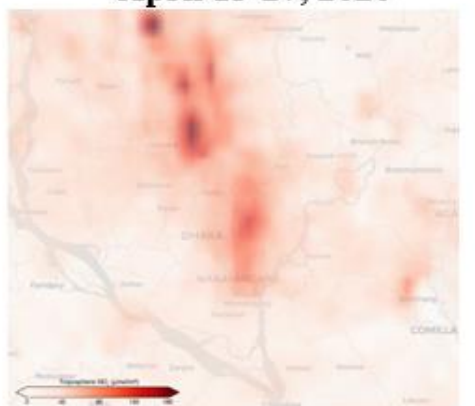

May 18-June 1, 2020

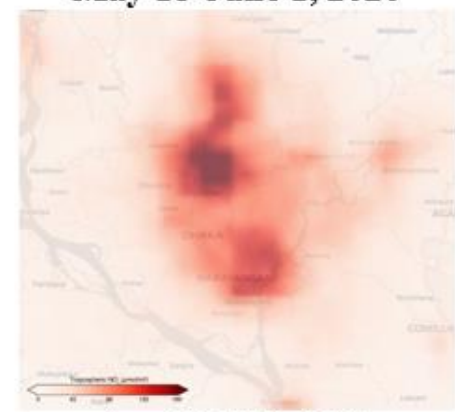

April 15-29, 2019

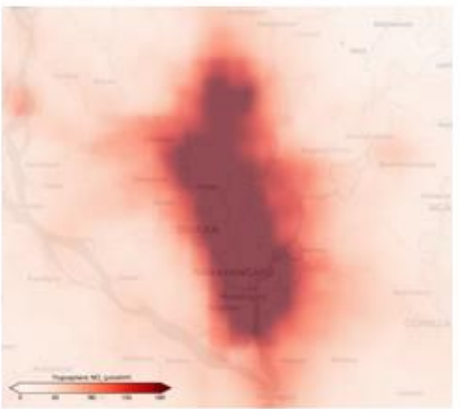

March 9-23, 2020

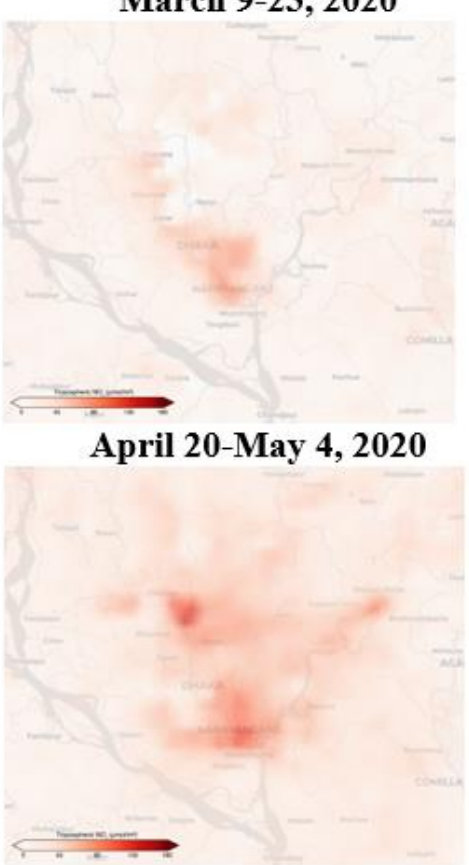

June 1-15, 2020

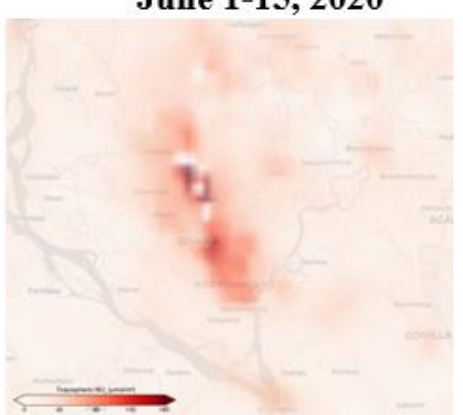

June 3-17, 2019

Fig. 4. $\mathrm{NO}_{2}$ concentrations before COVID-19 lockdown (March 2020), during lockdown (April 2020) and after limited scale lockdown (May and June 2020), and bottom panel was from similar time period but in 2019 over Dhaka, Bangladesh (Source: European Space Agency). 


\section{Variation of COVID-19 Morbidity and Mortality}

\section{With Air Quality Indicators}

Temporal variation of total confirmed COVID-19 cases, new cases, and daily deaths with $\mathrm{PM}_{10}$, $\mathrm{PM}_{2.5}$, and AQI in Dhaka has given in Fig. 5. The relationship between aerosol particle number and mass with SARS-CoV-2 virus has been studying but not fully understood yet. The high concentration of viral RNA has been observed when the submicron and/or super submicron particles having peaked in the aerosol size distribution curve (Liu et al., 2020). The relationship between COVID-19 morbidity and mortality cases and air quality index ( $\mathrm{PM}_{10}, \mathrm{PM}_{2.5}$, and AQI) was not linear (Fig. 5). The reason may be the particle sizes - $\mathrm{PM}_{2.5}$ and $\mathrm{PM}_{10}$ are much larger compared to the size of the SARS-CoV-2 virus. However, long term exposure to a high concentration of particulate air pollution might be attributed to bronchial asthma, chronic obstructive pulmonary diseases (COPD), chronic heart diseases, which might be one of the causes of the relatively high COVID-19 death rate in Dhaka.

\section{With Climate variables}

The variation of total COVID-19 confirmed cases, daily new cases, and total deaths with climate variables (temperate and relative humidity) in Dhaka from March 8, 2020 to June 16, 2020 has given in Fig. 6. The total number of COVID-19 confirmed cases and total deaths were increasing sharply in Dhaka. The temperature and relative humidity curve were also going up. The number of confirmed cases was 94,481 on June 16, 2020 with the total deaths of 1262 . However, the relationship between climate variables and COVID-19 cases is not well understood yet, may be many factors are responsible. But a strong linear relationship has been observed for the COVID-19 
medRxiv preprint doi: https://doi.org/10.1101/2020.09.12.20193086; this version posted September 13, 2020. The copyright holder for this preprint (which was not certified by peer review) is the author/funder, who has granted medRxiv a license to display the preprint in perpetuity.

It is made available under a CC-BY 4.0 International license .

total and deaths cases with temperature and relative humidity in Dhaka city (Fig. 6). Climate variables (e.g., temperature, relative humidity, wind velocity and rainfall) have a significant impact on the formation, dispersion and deposition of pollutants in the atmosphere. Ambient air pollutants with climate variables aggravated the pulmonary diseases and injured the respiratory pathways, and hence facilitated the virus to infect the human system and cause unadorned damages (Zoran et al., 2020).

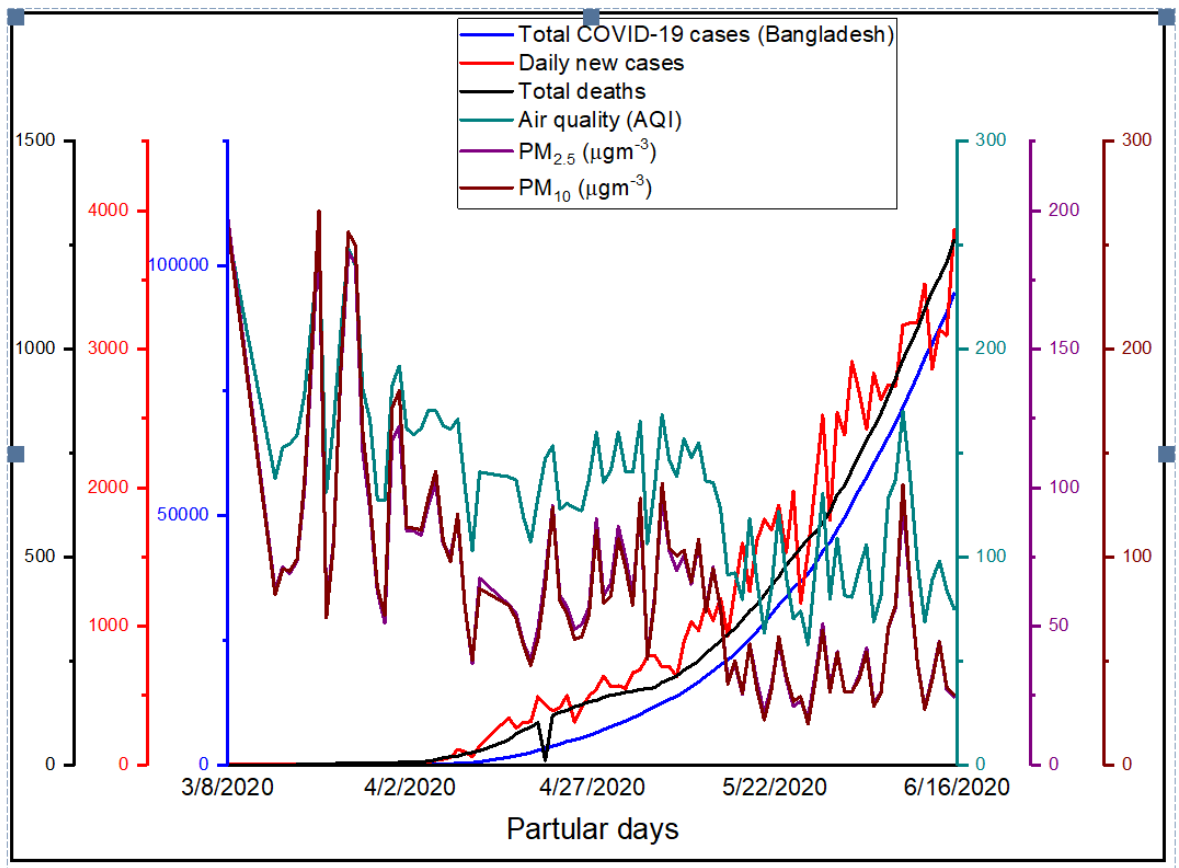

Fig. 5. Depiction of COVID-19 cases and air quality ( $\left.\mathrm{PM}_{2.5}, \mathrm{PM}_{10}, \mathrm{AQI}\right)$ from March 8 to June 16, 2020 in Bangladesh (Source: COVID-19 related data from Directorate General of Health Services, DGHS, Bangladesh).

\section{Kendall and Spearman Correlation Tests}

The Kendall and Spearman correlation tests were performed between the empirical data of $\mathrm{PM}_{2.5}$, $\mathrm{PM}_{10}, \mathrm{CO}_{2}$, and $\mathrm{AQI}$ and climate variables (temperature, relative humidity, wind velocity, and 
medRxiv preprint doi: https://doi.org/10.1101/2020.09.12.20193086; this version posted September 13, 2020. The copyright holder for this preprint (which was not certified by peer review) is the author/funder, who has granted medRxiv a license to display the preprint in perpetuity. It is made available under a CC-BY 4.0 International license.

rainfall) with COVID-19 morbidity and mortality. In both Kendall and Spearman correlation tests, we found significant negative correlation with air quality indicators $\left(\mathrm{PM}_{2.5}, \mathrm{PM}_{10}, \mathrm{CO}_{2}\right.$, and $\left.\mathrm{AQI}\right)$ with total confirmed COVID-19 cases, daily new cases, and mortality in Dhaka, Bangladesh (Table 2). The magnitude of the correlation coefficients of $\mathrm{PM}_{2.5}, \mathrm{PM}_{10}, \mathrm{CO}_{2}$, and AQI were lower in Kendall tests than the Spearman correlation. The air quality was good during lockdown period but the mortality and morbidity was high in Dhaka. Because the COVID-19 transmitted patients may be experiencing worst air quality from the previous months (January, February and March) of the year that have significant impact on their health. Patients organs (e.g., lung, heart, kidney, etc.) may already compromised by the long term exposure of the poor air quality in Dhaka. Some other factors (immune system, cofactors) may also be contributed to this significant negative correlation in Dhaka. In California, USA, Bashir et al. (2020b) also found similar results - $\mathrm{PM}_{2.5}, \mathrm{PM}_{10}, \mathrm{SO}_{2}$, $\mathrm{CO}$, and $\mathrm{NO}_{2}$ have significant negative correlation with total COVID-19 morbidity and mortality.

Whereas, the higher concentrations of $\mathrm{PM}_{10}$ and $\mathrm{PM}_{2.5}$ reported a positive correlation with death rate of COVID-19 in China (Yao et al., 2020). Fattorini and Regili, 2020 revealed that the primary cause of COVID-19 in Northern Italy was the continuous exposure of high levels of $\mathrm{PM}_{10}$ and $\mathrm{PM}_{2.5}$ (Fattorini and Regili, 2020). As a first-order approximation, the COVID-19 related morbidity and mortality in Dhaka are significantly correlated with the high exposure of air quality parameters, especially $\mathrm{PM}_{10}$ and $\mathrm{PM}_{2.5}$ like other cities in the World (e.g., California, Wuhan, and Northern Italy). The climate variables (average temperature, relative humidity, wind velocity, and rainfall) have strong positive correlation with the total COVID-19 confirmed and daily new cases, and mortality in Dhaka. 


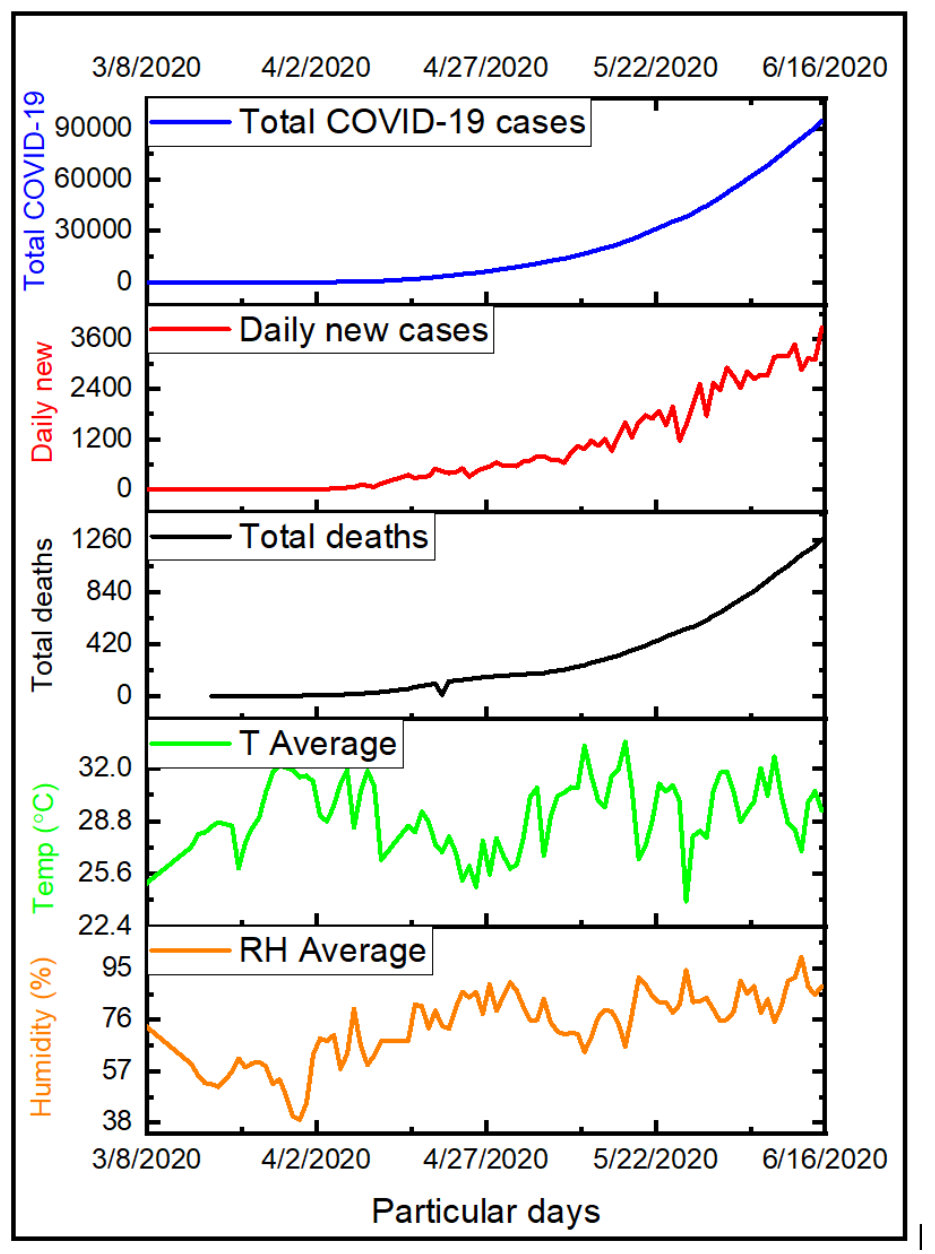

Fig. 6. Temporal variation of total number of COVID-19 cases, daily new cases, total deaths, daily mean climate variables (average air temperature and relative humidity) in Bangladesh (Source: COVID-19 related data from Directorate General of Health Services, DGHS, Bangladesh).

Previous studies of Vandini et al., (2013) and Bashir et al., (2020a) reported similar results and support our findings. Shi et al., 2020 reported that climate indicator (temperature) serves as a driver for the COVID-19. On the other hand, Méndez-Arriaga, (2020) reported a negative association of the air temperature with the total confirmed COVID-19 cases. COVID-19 outbreak at Wuhan, 
medRxiv preprint doi: https://doi.org/10.1101/2020.09.12.20193086; this version posted September 13, 2020. The copyright holder for this preprint (which was not certified by peer review) is the author/funder, who has granted medRxiv a license to display the preprint in perpetuity.

It is made available under a CC-BY 4.0 International license .

China showed a strong association between diseases spread and weather conditions, with a prediction of "warm weather will play an important role in suppressing the virus."

Table 2. Empirical results of correlation between air quality indicators and climate variables with total confirmed cases, new cases and mortality in Dhaka, Bangladesh.

\begin{tabular}{|c|c|c|c|c|}
\hline & Parameters & Total Cases & New Cases & Mortality \\
\hline Kendall Correlation & $\mathrm{PM}_{2.5}$ & $-0.350 *$ & $-0.234 *$ & $-0.306^{*}$ \\
\hline \multirow[t]{7}{*}{ Coefficient } & $\mathrm{PM}_{10}$ & $-0.329 *$ & $-0.219 * *$ & $-0.265^{*}$ \\
\hline & $\mathrm{CO}_{2}$ & $-0.312 *$ & $-0.315 * *$ & $-0.256^{*}$ \\
\hline & AQI & $-0.362 *$ & $-0.294 *$ & $-0.278^{*}$ \\
\hline & Average temperature & 0.161 & 0.108 & $0.202 * *$ \\
\hline & Relative humidity & $0.282 *$ & $0.232 *$ & 0.141 \\
\hline & Wind velocity & 0.031 & 0.060 & 0.035 \\
\hline & Rainfall & $0.191 * *$ & 0.159 & 0.095 \\
\hline Spearman Correlation & $\mathrm{PM}_{2.5}$ & $-0.523 *$ & $-0.351 *$ & $-0.438 *$ \\
\hline \multirow[t]{7}{*}{ Coefficient } & $\mathrm{PM}_{10}$ & $-0.495 *$ & $-0.418 *$ & $-0.414 *$ \\
\hline & $\mathrm{CO}_{2}$ & $-0.426 *$ & $-0.445^{* *}$ & $-0.376^{*}$ \\
\hline & AQI & $-0.532 *$ & $-0.430 *$ & $-0.421 *$ \\
\hline & Average temperature & $0.249 * *$ & 0.158 & $0.309 * *$ \\
\hline & Relative humidity & $0.408 *$ & $0.324 * *$ & 0.207 \\
\hline & Wind velocity & 0.063 & 0.099 & 0.053 \\
\hline & Rainfall & $0.303 * *$ & 0.208 & 0.205 \\
\hline
\end{tabular}


However, temperature and relative humidity may play a significant role in COVID-19 transmission and also have a substantial role in the mortality rate (Auler et al., 2020; Poole, 2020; Sajadi et al., 2020; Chen et al., 2020a; Ma et al., 2020; Wang et al., 2020b). Other meteorological indicators such as wind velocity and rainfall also showed a significant positive correlation with COVID-19 cases in Dhaka, Bangladesh.

Dhaka, as an administrative, cultural, and economic center of Bangladesh, experiences a high influx of population from all over the country for seeking employment, education, business, and medical treatments. Moreover, many people are living not only in the slums but also in the inappropriate substandard houses with inadequate facilities and very limited medical access with the worst air quality. All these made the COVID-19 situation in Dhaka uncontrollable and hence withstand with a large number of COVID-19 confirmed and death cases for a comparatively long period. Therefore, our study will supplement new knowledge for decision-makers that air quality and climate variables are two important constraints that need to be addressed for controlling the transmission of the SARS-CoV-2 virus in the developing countries.

\section{Conclusion}

Air quality parameters $\left(\mathrm{PM}_{2.5}, \mathrm{PM}_{10}, \mathrm{AQI}, \mathrm{NO}_{2}\right.$, and $\left.\mathrm{CO}_{2}\right)$ and climate variables (average temperature, relative humidity, rainfall, and wind velocity) were studied before and during the COVID-19 pandemic from March 8, 2020, to June 16, 2020, in Dhaka, Bangladesh. The study revealed the impact of COVID-19 precautions on Dhaka air quality. The Kendall and Spearman correlation tests were performed to see the correlation between COVID-19 morbidity and mortality cases with climate variables and air quality indicators. The air quality has drastically reduced in 
medRxiv preprint doi: https://doi.org/10.1101/2020.09.12.20193086; this version posted September 13, 2020. The copyright holder for this preprint (which was not certified by peer review) is the author/funder, who has granted medRxiv a license to display the preprint in perpetuity.

It is made available under a CC-BY 4.0 International license .

Dhaka due to COVID-19 lockdown in April 2020 (on average, about 2.5 times lower PM2.5 and 6 times lower $\mathrm{NO}_{2}$ observed than a normal period). $\mathrm{PM}_{2.5}, \mathrm{PM}_{10}, \mathrm{CO}_{2}$, air quality index (AQI) has no positive but a significant correlation (within 1.0\%) with the number of COVID-19 confirmed cases

and mortality. Average temperature, minimum temperature, and wind velocity have a strong positive correlation with COVID-19 confirmed morbidity and mortality cases in Dhaka. These findings will be helpful for policymakers to understand the mitigation mechanism of the air quality and also will be useful for future research to control the SARS-CoV-2 virus as well as air quality.

\section{Acknowledgement}

Authors acknowledge the data support to Air visual (www.iqair.com), European space agency $\left(\mathrm{NO}_{2}\right.$ satellite images), DGHS, Bangladesh (COVID-19 related data at www.dghs.gov.bd) and for climate variables data (www.darksky.net and www.weatherforyou.com).

\section{Funding Support}

This research did not receive any specific grant from any funding agencies in the public, commercial, or not-for-profit sectors. But we are using our research support of the Department of Chemistry, University of Dhaka, Bangladesh.

\section{References}

Auler, A.C., Cássaro, F.A.M., da silva, V.O., Pires, L.F. (2020). Evidence that high temperatures and intermediate relative humidity might favor the spread of COVID-19 in tropical climate: A 
medRxiv preprint doi: https://doi.org/10.1101/2020.09.12.20193086; this version posted September 13, 2020. The copyright holder for this preprint (which was not certified by peer review) is the author/funder, who has granted medRxiv a license to display the preprint in perpetuity.

It is made available under a CC-BY 4.0 International license .

case study for the most affected Brazilian cities. Sci. Total Environ. 729:139090. doi.org/10.1016/j.scitotenv.2020.139090.

Bashir, M.F., Ma, B., Bilal, Komal, B., Bashir, M.A., Tan, D., Bashir, M. (2020a). Correlation between climate indicators and COVID-19 pandemic in New York, USA. Sci. Total Environ. 728:138835. doi.org/10.1016/j.scitotenv.2020.138835.

Bashir, M.F., Ma, B., Bilal, B.M., Komal, B., Bashir, M.A., Farooq, T.H., Iqbal, N., Bashir, M. (2020b). Correlation between environmental pollution indicators and COVID-19 pandemic: A brief study in Californian context. Environ. Res. 187:109652. doi.org/10.1016/j.envres.2020.109652.

Bauwens, M., Compernolle, S., Stavrakou, T., Müller, J.-F., van Gent, J., Eskes, H., et al. (2020). Impact of coronavirus outbreak on $\mathrm{NO}_{2}$ pollution assessed using TROPOMI and OMI observations. Geophys. Res. Lett. 47:11. https://doi.org/10.1029/2020GL087978.

Bukhari, Q., Jameel,Y. (2020). Will Coronavirus Pandemic Diminish by Summer? (March 17, 2020). SSRN. dx.doi.org/10.2139/ssrn.3556998.

Chauhan, A., Singh, R.P. (2020). Decline in $\mathrm{PM}_{2.5}$ concentrations over major cities around the world associated with COVID-19. Environ Res. 187:109634. doi.org/10.1016/j.envres.2020.109634.

Chen, B., Liang, H., Yuan, X., Hu, Y., Xu, M., Zhao, Y., Zhang, B., Tian, F., Zhu, X. (2020a). Roles of Meteorological Conditions in COVID-19 Transmission on a World wide Scale. medRxiv. doi.org/10.1101/2020.03.16.20037168. 
Chen, K., Wang, M., Huang, C., Kinney, P.L., Anastas, P.T. (2020b). Air pollution reduction and mortality benefit during the COVID-19 outbreak in China. Lancet Planet. Health. 4(6):210-212. doi.org/10.1016/S2542-5196(20)30107-8.

Fattorini, D., Regoli F. (2020). Role of the chronic air pollution levels in the Covid-19 outbreak risk in Italy. Environ. Pollut. 264:114732. doi.org/10.1016/j.envpol.2020.114732.

Hopkins, John. (2020). John Hopkins University of Medicine. Coronavirus Research Center. 20. https://coronavirus.jhu.edu/map.html (Accessed April 17 2020).

IQAir, COVID-19 Air Quality Report. 2019 coronavirus pandemic lockdowns result in unprecedented reductions in deadly particle pollution (Apr. 22, 2020). https://www2.iqair.com/sites/default/files/documents/REPORT-COVID-19-Impact-on-AirQuality-in-10-Major-Cities_V6.pdf.

Le, T., Wang, Y., Liu, L., Yang, J., Yung, Y.L., Li, G., Seinfeld, J.H. (2020). Unexpected air pollution with marked emission reductions during the COVID-19 outbreak in China. Science. doi.10.1126/science.abb7431.

Le Quéré, C., Jackson, R.B., Jones, M.W., Smith, A.J.P., Abernethy, S., Andrew, R.M., De-Gol1, A.J., Willis, D.R., Shan, Y., Canadell, J.G., Friedlingstein, P., Creutzig, F., Peters, G.P. (2020). Temporary reduction in daily global $\mathrm{CO}_{2}$ emissions during the COVID-19 forced confinement. Nat. Clim. Chang. 10:647-653. https://doi.org/10.1038/s41558-020-0797-x.

Li, Q., Guan, X., Wu, P., Wang, X., Zhou, L., Tong, Y., Ren, R., Leung, K.S.M., Lau, E.H.Y., Wong, J.Y., Xing, X., Xiang, N., Wu, Y., Li, C., Chen, Q., Li, D., Liu, T., Zhao, J., Liu, M., Tu, W., Chen, C., Jin, L., Yang, R., Wang, Q., Zhou, S., Wang, R., Liu, H., Luo, Y., Liu, Y., Shao, G., Li, H., Tao, Z., Yang, Y., Deng, Z., Liu, B., Ma, Z., Zhang, Y., Shi, G., Lam, T.T.Y., Wu, 
medRxiv preprint doi: https://doi.org/10.1101/2020.09.12.20193086; this version posted September 13, 2020. The copyright holder for this preprint (which was not certified by peer review) is the author/funder, who has granted medRxiv a license to display the preprint in perpetuity.

It is made available under a CC-BY 4.0 International license .

J.T., Gao, G.F., Cowling, B.J., Yang, B., Leung, G.M., Feng, G. (2020). Early transmission dynamics in Wuhan, China, of novel coronavirus infected pneumonia. N. Engl. J. Med. 382:1199-1207. doi.org/10.1056/NEJMoa2001316. NEJMoa2001316.

Liu, Y., Ning, Z., Chen, Y., Guo, M., Liu, Y., Gali, N.K., Sun, L., Duan, Y., Cai, J., Westerdah, D., Liu, X., Xu, K., Ho, K.-F., Kan, H., Fu, Q., Lan, K. (2020). Aerodynamic analysis of SARSCoV-2 in two Wuhan hospitals. Nature. 582:557-560. doi.org/10.1038/s41586-020-2271-3.

Ma, Y., Zhao, Y., Liu, J., He, X., Wang, B., Fu, S., Yan, J., Niu, J., Zhou, j., Luo, B. (2020). Effects of temperature variation and humidity on the death of COVID-19 in Wuhan, China. Sci. Total Environ. 724:139226. doi.org/10.1016/j.scitotenv.2020.138226.

Méndez-Arriaga, F. (2020). The temperature and regional climate effects on communitarian COVID-19 contagion in Mexico throughout phase 1. Sci. Total Environ. 735:139860. doi.org/10.1016/j.scitotenv.2020.139560.

Poole, L. (2020). Seasonal Influences On the spread of SARS-CoV-2 (COVID19), Causality, and Forecast ability (3-15-2020). SSRN. dx.doi.org/10.2139/ssrn.3554746.

Rahman, M.M., Begum, B.A., Hopke, P.K, Nahar, K., Thurston, G.D. (2020). Assessing the PM 2.5 impact of biomass combustion in megacity Dhaka, Bangladesh. Environ. Pollut. 264:114798. doi.org/10.1016/j.envpol.2020.114798.

Sajadi, M.M., Habibzadeh, Pa., Vintzileos, A., Shokouhi, S., Miralles-Wilhelm, F., Amoroso, A. (2020). Temperature, Humidity and Latitude Analysis to Predict Potential Spread and Seasonality for COVID-19. SSRN. dx.doi.org/10.2139/ssrn.3550308. 
medRxiv preprint doi: https://doi.org/10.1101/2020.09.12.20193086; this version posted September 13, 2020. The copyright holder for this preprint (which was not certified by peer review) is the author/funder, who has granted medRxiv a license to display the preprint in perpetuity.

It is made available under a CC-BY 4.0 International license .

Salam, A., Bauer, H., Kassin, K., Mohammad Ullah, S., Puxbaum, H. (2003). Aerosol chemical characteristics of a mega-city in Southeast Asia (Dhaka-Bangladesh). Atmos. Environ. 37:25172528. doi.org/10.1016/S1352-2310(03)00135-3.

Salam, A., Al Mamoon, H., Ullah, M.B., Ullah, S.M. (2012). Measurement of the atmospheric aerosol particle size distribution in a highly polluted mega-city in Southeast Asia (DhakaBangladesh). Atmos. Environ. 59:338-343. doi.org/10.1016/j.atmosenv.2012.05.024.

Schiermeier, Q. (2020). Why pollution is falling in some cities- but not others. Nature. 580:313. doi.org/10.1038/d41586-020-01049-6.

Sharma, S., Zhang, M., Anshika, Gao, J., Zhang, H., Kota, S.H. (2020). Effect of restricted emissions during COVID-19 on air quality in India. Sci. Total Environ. 728:138878. doi.org/10.1016/j.scitotenv.2020.138878.

Shereen, M.A., Khan, S., Kazmi, A., Bashir, N., Siddique, R. (2020). COVID-19 infection: origin, transmission, and characteristics of human coronaviruses. J. Adv. Res. 24:91-98. doi.org/10.1016/j.jare.2020.03.005.

Shi, P., Dong, Y., Yan, H., Li, X., Zhao, C., Liu, W., He, M., Tang, S., Xi, S. (2020). The Impact of Temperature and Absolute Humidity on the Coronavirus Disease 2019 (COVID-19) Outbreak Evidence from China. medRxiv. doi.org/10.1101/2020.03.22.20038919.

Sohrabi, C., Alsafi, Z., O’Neill, N., Khan, M., Kerwan, A., Al-Jabir, A., Iosifidis, C., Agha, R. (2020). World Health Organization declares global emergency: a review of the 2019 novel coronavirus (COVID-19). Int. J. Surg. 76:71-76. doi.org/ 10.1016/j.ijsu.2020.02.034. 
medRxiv preprint doi: https://doi.org/10.1101/2020.09.12.20193086; this version posted September 13, 2020. The copyright holder for this preprint (which was not certified by peer review) is the author/funder, who has granted medRxiv a license to display the preprint in perpetuity.

It is made available under a CC-BY 4.0 International license .

Vandini, S., Corvaglia, L., Alessandroni, R., Aquilano, G., Marsico, C., Spinelli, M. (2013). Respiratory syncytial virus infection in infants and correlation with meteorological factors and air pollutants. Ital. J. Pediatr. 39(1). doi.org/10.1186/1824-7288-39-1.

Wang, D., Hu, B., Hu, C., Zhu, F., Liu, X., Zhang, J., Wang, B., Xiang, H., Cheng, Z., Xiong, Y., Zhao, Y., Li, Y., Wang, X., Peng, Z. (2020a). Clinical characteristics of 138 hospitalized patients with 2019 novel coronavirus infected pneumonia in Wuhan, China. J. Am. Med. Assoc. 323 (11):1061. doi.org/10.1001/jama.2020.1585.

Wang, M., Jiang, A., Gong, L., Luo, L., Guo, W., Li, C., Zheng, J., Li, C., Yang, B., Zeng, J., Chen, Y., Zheng, K., Li, H. (2020b). Temperature Significant Change COVID-19 Transmission in 429 Cities. medRxiv. doi.org/10.1101/2020.02.22.20025791.

WHO Director. (2020a). General's Remarks at the Media Briefing on 2019-nCoV on 11 February 2020. www.who.int/dg/speeches/detail/who-director-generals-remarks-at-the-media-briefing-on2019-ncov-on-11-february-2020.

WHO Director. (2020b). General's Opening Remarks at the Media Briefing on COVID19 on 11 March 2020. www.who.int/dg/speeches/detail/whodirector-general-s-opening-remarks-at-themedia-briefing-on-covid-19-11march-2020.

Wu, F., Zhao, S., Yu, B., Chen, Y.-M., Wang, W., Song, Z.-G., Tao, Z.-W., Tian, J.-H., Pei, Y.-Y., Yuan, M.-L., Zhang, Y.-L., Dai, F.-H., Liu, Y., Wang, Q.-M., Zheng, J.-J., Xu, L., Holmes, E.C., Zhang, Y.-Z. (2020a). A new coronavirus associated with human respiratory disease in China. Nature. 579(7798):265-269. doi.org/10.1038/s41586-020-2008-3. 
medRxiv preprint doi: https://doi.org/10.1101/2020.09.12.20193086; this version posted September 13, 2020. The copyright holder for this preprint (which was not certified by peer review) is the author/funder, who has granted medRxiv a license to display the preprint in perpetuity. It is made available under a CC-BY 4.0 International license .

Wu, X., Nethery, R. C., Sabath, B. M., Braun, D., and Dominici, F. (2020b). Exposure to air pollution and COVID-19 mortality in the United States: A nationwide cross-sectional study. medRxiv. doi.org/10.1101\%2F2020.04.05.20054502.

Xu, B., Gutierrez, B., Mekaru, S., Sewalk, K., Goodwin, L., Loskyll, A., Cohn, E.L., Hswen, Y., Hill, S.C., Cobo, M.M., Zarebski, A.E., Li, S., Wu, C.-H., Hulland, E., Morgan, J.D., Wang, L., O’Brien, K., Scarpino, S.,V., Brownstein, J.S., Pybus, O.G., Pigott, D.M., Kraemer, M.U.G. (2020). Epidemiological data from the COVID-19 outbreak, real-time case information. Scientific Data. 7(1). doi.org/10.1038/s41597-020-0448-0.

Yao, Y., Pan, J., Wang, W., Liu, Z., Kan, H., Qiu, Y., Meng, X., Wang, W. (2020). Association of particulate matter pollution and case fatality rate of COVID-19 in 49 Chinese cities. Sci. Total Environ. In Press, Journal Pre-proof. doi.org/10.1016/j.scitotenv.2020.140396.

Zoran, M.A., Savastru, R.S., Savastru, D.M., Tautan, M.N. (2020). Assessing the relationship between surface levels of $\mathrm{PM}_{2.5}$ and $\mathrm{PM}_{10}$ particulate matter impact on COVID-19 in Milan, Italy. Sci. Total Environ. 738:139825. doi.org/10.1016/j.scitotenv.2020.139825. 